\title{
Structures of Violence and the Denigration of Law in Christian Thought ${ }^{1}$
}

\author{
BARBARA U. MEYER \\ barmeyer@post.tau.ac.il \\ Tel Aviv University, Tel Aviv 6997801, Israel
}

\section{Introduction}

This essay examines structures of violence in traditions of Christian theological thought. While it presupposes the historical fact of real violence resulting from Christianity, it focuses on patterns of aggressive thinking in Christian theory that need neither immediately nor necessarily be translated into physical violence. I begin my inquiry with a thought pattern that has been recognized as the core Christian mechanism of delegitimizing Judaism, supersessionism. I then move on to analyze two other key thought patterns of Christian violence, "realized eschatology" and "inclusivism," both of which have received less attention from Christian and Jewish scholars. In my discussion of the central place that Judaism holds in the history of Christian aggression, I will further ask whether and how this aggression also affects Islam. Throughout, I pay special attention to the Christian approach to law that I suggest holds the key to both disrespect and potential respect for Judaism and Islam.

My assessment of violent patterns in interreligious thought avoids identifying whole religions with violence, an approach that has become popular in certain political assessments of Islam and, remarkably, also in some of the recent academic literature on Christianity. Finding patterns also means, methodologically, that I am not looking for unique instances or single-solution paradigms; rather, I discuss specific mechanisms of violent thought that can be subject to modification. I ask how each of these negative motifs has been confronted and challenged in contemporary Christian thought. Finally, I will ask how these motifs affect the broader interreligious discourse, including Islam, and how certain post-Shoah approaches to confronting interreligious delegitimization can be relevant to JewishChristian-Muslim relations today.

How can "violence in thought" be described and analyzed? In historical Christianity, structures of violence display complexity; the various structures appear together and separately and in various combinations with other social and

\footnotetext{
${ }^{1}$ The research for this article was supported by the Israel Science Foundation.
} 
political factors. The limitations of recent attempts to explain Christian aggression with single-source mechanisms underline the importance of further research on an issue that currently divides scholars who present violent thinking as inherent to Christian identity from those who view aggression towards others mainly as a historical reality of Christianity, dependent on specific time, place and context. My inquiry into structures of thought suggests methodologically that interreligious violence is a highly complex phenomenon that can actually be reduced or increased.

\section{Violence in Theory and Praxis}

While there is no clear-cut correlation between violent thought and violent action, nevertheless the apologetic concept of "harmless" thought has invariably been proven wrong in the history of Christian anti-Jewish traditions. According to Friedrich-Wilhelm Marquardt, the most important Christian post-Shoah theologian, there has never been a solely spiritual judgment about Jews that did not eventually cause a chain of completely unspiritual, purely political events. ${ }^{2}$ Christian as well as Jewish scholars agree today that anti-Judaism is not at the margins of Christian aggression, but at its center. Among Christians, this conclusion has arisen mainly among systematic theologians rather than historians, among them Rosemary Radford Ruether, Alice Eckardt and Roy Eckardt, Friedrich Wilhelm Marquardt and John T. Pawlikowski. ${ }^{3}$

What remains unclear is the question of how aggression against Jews and Judaism relates to other modes of violence in Christian thought. So far, not much attention has been paid to this question, perhaps because of a lack of communication between those researching antisemitism and those studying Christian thought. Among the patterns of traditional Christian thought that have been identified as aggressive by systematic theologians, the most obvious are the phenomena of supersessionism and historicized eschatology (to be discussed below). A third, that I describe as "inclusivism," has only recently been detected as underlying missionary thought.

I am going to explain the theological reasoning for each of these forms of Christian aggression before also translating them into secular language. The choice of these three patterns does not suggest a comprehensive account of Christian aggression. But it strongly underlines the complexity of Christian aggression and thus challenges recent descriptions of single-source or single mechanism explanations for Christian violence, whether presented as a historical overview (Nirenberg), metaphoric, associative critique (Anidjar) or byproduct of a (very interesting) Jewish diaspora-theory (Boyarin).

\footnotetext{
${ }^{2}$ Cf. Friedrich-Wilhelm Marquardt, Von Elend und Heimsuchung der Theologie. Prolegomena zur Dogmatik, 2nd edition (München: Kaiser, 1992), 105.

${ }^{3}$ Rosemary Radford Ruether's analysis has been fundamental in this matter. See her Faith and Fratricide: The Theological Roots of Anti-Semitism (Eugene, OR: Wipf \& Stock, 1997 [first published New York: Seabury, 1974]).
} 


\section{A. Supersessionism}

\section{Christian Supersessionist Reasoning}

Christian theologians of all denominations traditionally connected a presumed replacement of Judaism with the notion of the church as "true Israel." This has recently been described as an act of trying to take someone else's blessing away and apply it solely to oneself. ${ }^{4}$ In contemporary academic language, the idea of Christianity replacing Judaism is usually called "supersessionism," a term developed by Western self-critical Christian theologians. "This approach has been marked as a theological wrong, that is, both morally wrong and a theological mistake.

Until the mid-twentieth century, the idea of the new covenant superseding the old one was prevalent in all of Christianity, although it was arguably never explicit Pauline thought nor part of the Christian Creed. The formation of the Christian canon also neither suggests nor implies this, as one might think, in the very naming of an "Old" versus a "New" Testament: all Christian denominations hold the "Old Testament" holy as the first part of the Christian Holy Scriptures. The idea that a new covenant has replaced an old and thereby obsolete covenant was in fact never the dogma of the early Church or Scripture. It has been at most a tradition, albeit one that has had a powerful impact in all major Christian denominations and churches. The fact that supersessionism is not inherent to Christianity has enabled theologians as well as Church representatives and synods to renounce it. This happened in the last third of the twentieth century in all major mainstream Western churches. (Orthodox churches have had a different history with the concept and thus require a different contemporary discussion ${ }^{6}$ ).

Christian self-critical assessments often treat supersessionism and antiJudaism as synonyms. While both delegitimize Judaism, the two terms comprise very different categories of aggressive thought-patterns. Supersessionism describes a specific and fixed interreligious construction of history. Christian antiJudaism, on the other hand, encompasses a wide range of readings of scripture and traditions through the prejudiced lens of Jewish spiritual inferiority. The difference between the two forms of aggression is only partly manifest in the intensity of aggression. Christian supersessionism implies that Judaism is obsolete and no longer necessary while Christian anti-Judaism engages in negative characterizations of Jews and Judaism. Both patterns can declare Judaism unworthy as a whole and both can be expressed in common terms of religious superiority. When "exported" and applied beyond the Jewish-Christian relation-

\footnotetext{
${ }^{4}$ Cf. Mary Boys, Has God Only One Blessing? Judaism as a Source of Christian Self-Understanding (Mahwah, NJ: Paulist Press, 2000). The rhetorical question in the title suggests sharing God's blessing is an appropriate option for Christianity.

${ }^{5}$ Kendall Soulen, The God of Israel and Christian Theology (Minneapolis: Augsburg Fortress, 1996), $2-5$.

${ }^{6}$ Cf. Harold Smith, "Supersession and Continuance: The Orthodox Church's Perspective on Supersessionism," in Journal of Ecumenical Studies 49 no. 2 (Spring 2014): 247-273.
} 
ship, the key difference between replacing and degrading another religious community becomes more critical, as we will see.

Modern academic literature on Christian anti-Judaism has generated a variety of genres. James Parkes' analyses at the beginning of the twentieth century confronted a Christianity in which all mainstream churches held anti-Jewish hermeneutics as a given truth. ${ }^{7}$ Starting in the late 1940s, the American theologian Roy Eckardt began systematically to disrupt this identification of Christian truth with anti-Jewish traditions. ${ }^{8}$

In 1948, in the immediate aftermath of World War II and the Shoah, the World Council of Churches declared antisemitism a "sin." Antisemitism, in this period, was understood as statements explicitly degrading Jews, while the more complex forms of Christian anti-Judaism were not yet studied, let alone understood. Historians researching Jewish-Christian relations then began to catch the attention of a number of Church leaders, leading to profound changes in church history, for example, the famous 1960 meeting between the Jewish historian Jules Isaac and Pope John XXIII that eventually led to Nostra Aetate, the document that facilitated a renewal of the Catholic approach to Jews and Judaism. The text of Nostra Aetate $\S 4$ alludes to both supersessionism and anti-Judaism when it affirms the ongoing significance of Judaism for Christianity and rejects Jewish culpability for Jesus' death.

In the seventies and early eighties, several Christian theologians adopted critical analyses of anti-Judaism as substantial components of their new approach. In the United States, Roy Eckardt continued to be a pioneering voice within systematic theology, while in the German-speaking context, Friedrich-Wilhelm Marquardt dedicated most of the path-breaking first volume of his dogmatics to the theological analysis of academic anti-Jewish theology. Remarkably, Catholics and Protestants have been very close to each other in their respective readings of anti-Judaism.

Awareness of Christian anti-Jewish hermeneutics developed mainly in the exegetical disciplines, in Old and New Testament studies - and, remarkably, among theologically well informed lay Church initiatives and synod forums. Thus even some regional and local church documents display impressive analytical insights, such as, for example, the Rhineland synod statement with its critique of common Christian understandings of "new" and "old":

Throughout centuries the word "new" has been used in biblical exegesis against the Jewish people: the new covenant was understood in contrast to the old covenant, the new people of God as replacement of the old people of God. This disrespect to the permanent election of the Jewish people and its condemnation to non-existence marked Christian theology, the preaching and work of the church again and again, right to the present day. Thereby we

\footnotetext{
${ }^{7}$ James Parkes, The Conflict of the Church and the Synagogue: A Study in the Origins of Antisemitism (London: Soncino Press, 1934).

${ }^{8}$ A. Roy Eckardt, Christianity and the Children of Israel (New York: King's Crown Press, 1948).
} 
have made ourselves guilty also of the physical elimination of the Jewish people. Therefore, we want to perceive the unbreakable connection of the New Testament with the Old Testament in a new way, and learn to understand the relationship of the "old" and "new" from the standpoint of the promise: in the framework of the given promise, the fulfilled promise and the confirmed promise. "New" means therefore no replacement of the "old." Hence we deny that the people Israel has been rejected by God or that it has been superseded by the church. ${ }^{9}$

The same document also contains a confession about Christian responsibility for advancing Antisemitism. The connection between Christian anti-Judaism and the Shoah was frequently conceded, while the discussion about definitions and mechanisms of anti-Jewish hermeneutics continued. Remarkably, among the critics of anti-Judaism it was often the case that the committed Christian academics proved more radical than their secular colleagues. ${ }^{10}$

At the same time, interreligious dynamics changed in academia: Christian theologians published general accounts of the Christian anti-Jewish tradition, often learned from their Jewish colleagues, as part of their theological or exegetical work (e.g., E.P. Sanders). Jewish historians began to engage in comparative studies of the Second Temple Period while profoundly transforming New Testament studies (in particular, the scholars David Flusser and Geza Vermes). This began a process known as the "third quest" that led to a complete reversal in research on the historical Jesus; the minority approach emphasizing the Jewish context of Jesus now became mainstream . ${ }^{11}$

That Christian scholarly inquiries into anti-Judaism have often been part of constructive theological publications also might explain their limited reception in historical disciplines. For instance, in the late 1980s and early 1990s, Christian academic works on anti-Judaism merged with post-Shoah theology. The best example is Roy and Alice Eckardt's Long Night's Journey into Day. ${ }^{12}$ In a highly original twist, the Eckardts answered the often-repeated question about the Shoah's uniqueness by instead labeling the multi-layered phenomenon of antisemitism as itself unique. With this view they refrained from comparing the suffering of individuals or collectives, but at the same time expressed Christian

\footnotetext{
${ }^{9}$ Zur Erneuerung des Verhältnisses von Christen und Juden. Handreichung der Evangelischen Kirche im Rheinland (Düsseldorf: Evangelische Kirche im Rheinland, 1980). An English translation by Franklin Littell (revised by R. Rendtorff) is available online. See "Towards Renovation of the Relationship of Christians and Jews,"

http://www.jcrelations.net/Towards_Renovation_of_the_Relationship_of_Christians_and_Jews.2388. 0. html?id=720\&L=3\&searchText=Erneuerung\&searchFilter $=\% 2 \mathrm{~A}$.

${ }^{10}$ See, for example, the New Testament scholar Lloyd Gaston, especially his article "Legicide," http://www.jcrelations.net/Legicide.2192.0.html?id=720\&L=3\&searchText=Gaston\&searchFilter=\% $\underline{2 \mathrm{~A}}$.

${ }^{11}$ Among the abundant recent literature on the so-called "third quest" in Historical Jesus research that focuses on Jesus' Jewish context, see Wolfgang Stegemann, Jesus und seine Zeit (Stuttgart: Kohlhammer, 2009), especially 113-123.

${ }^{12}$ Alice and A. Roy Eckardt, Long Night's Journey into Day: A Revised Retrospective on the Holocaust (Detroit: Wayne State University Press, 1988).
} 
responsibility for the various aggressive dynamics of antisemitism. The book as a whole presents the critique of Christianity with regard to Judaism as the main content of Christian post-Shoah theology. Yet theologians like Eckardt and Marquardt were far from re-legitimizing Christianity by criticizing its anti-Judaism. Their works eventually left open the question of whether Christian theology could ever recover from its failures. All of these works differentiated carefully between dogma, doctrine and tradition. No matter how sharp their criticisms of Christianity, the churches and Christian theology - and Eckardt and Marquardt were not inclined to hold back - they refused to essentialize Christianity as anti-Jewish. Essentialism, a term they did not use, was to them a variation of cheap apology which would only serve to exonerate modern theologians while indicting the Church Fathers. Thus, in their view, to refrain from essentializing was "lectio difficilior," the more difficult but more truthful task, and the appropriate way to take responsibility as academic theologians for an academic theological thought tradition.

It is important to understand this background in order to appreciate the gap between these works and more recent accounts of Christianity which characterize it as essentially anti-Jewish (Nirenberg), as striving for the eradication of difference (Boyarin), and as "bloody" (Anidjar). Nirenberg observes that the early Christian conceptualization of "Judaizing," projected as an undesirable closeness to Judaism, constructed real as well as imagined Jewishness as Christianity's enemy. ${ }^{13}$ Neither Eckardt's and Marquardt's historical examples nor their analyses differ much from Nirenberg's observations - but the meta-text is entirely opposite, as they see Christian theological reflection as obliged to discontinue this mechanism as well as capable of that task.

The difference in perspective is even more blatant in the case of Boyarin. As the hermeneutical key for his reading of Paul, he points to the famous verse of Galatians 3:28, "There is neither Jew nor Greek; there is neither slave nor freeman; there is no male and female. For you are all one in Christ Jesus." ${ }^{14}$ Boyarin sees this as the cause of Christianity's missionary ambition and practice. The Christian urge for comprehensive integration left no place for difference. This is very similar to Marquardt's formulations of Auschwitz's standing for the eradication of otherness. ${ }^{15}$ However, for Marquardt this is the worst of all configurations of Christianity, while for Boyarin, it is its essence.

Gil Anidjar offers an entirely different kind of presentation of Christianity and violence in his volume entitled Blood. ${ }^{16}$ It is to his credit that he introduces a discourse about "The Christian Question" so as to disturb the status quo of Christianity as "asking" about others rather than being questioned itself. ${ }^{17}$ But instead

\footnotetext{
${ }^{13}$ David Nirenberg, Anti-Judaism: The Western Tradition (New York: W.W. Norton, 2013).

${ }^{14}$ Daniel Boyarin, A Radical Jew: Paul and the Politics of Identity (Berkeley and Los Angeles: University of California Press, 1997), 23.

${ }^{15}$ Friedrich-Wilhelm Marquardt, Was dürfen wir hoffen, wenn wir hoffen dürften? Eine Eschatologie, vol. I (Gütersloh: Kaiser, 1993), 183.

${ }^{16}$ Gil Anidjar, Blood: A Critique of Christianity (New York: Columbia University Press, 2014).

${ }^{17}$ Anidjar, vii.
} 
of displaying a substantive analysis of Christianity's metaphoric as well as historical affiliation with "blood," Anidjar employs the term in multiple indeterminate ways. While he impressively proliferates the vocabulary of seemingly neutral terms connected to blood (e.g., "hematological" or "hematopoietic"), ultimately, in his account, he closely connects blood to violence and "hemophilia," also a term indicating violence. Anidjar explicitly rejects ascribing an essence of Christianity ${ }^{18}$ but in fact he presents "blood" not as a general component of life but as a Christian-specific sign implying in-built violence. Since, in this depiction of Christianity, blood is central, violence becomes constitutive as well as irreducible. The result is a Christianity essentialized as violence. Anidjar's rhetorical and academic style is unlike that of either Boyarin or Niremberg. Still, a focus on violence as the DNA of Christianity is common to all three approaches.

My investigation differs from these accounts methodologically. Rather than starting with an analysis of anti-Jewish violence, I begin with structures and mechanisms of aggressive thinking and then ask about the specific role accorded to Jews and Judaism in any of these various patterns. I also examine the role of law in these patterns of violent thought: Law has played a central role in recent critical re-reading of New Testament texts, and its conceptual analysis still holds undiscovered potential for the re-formulation of Jewish-Christian-Muslim relations.

\section{Is Supersessionism Genocidal?}

Since the 1990s, a broader consensus criticizing Christian supersessionism has grown among a wide array of Christian as well as Jewish scholars. Despite, or maybe because of this, little effort has been made to provide a deeper analysis of the matter in the contexts of interreligious as well as post-Shoah thought, both of which rely upon but also transcend the Christian-Jewish relationship.

The renunciation of supersessionism and the commitment to formulating non-supersessionist Christologies originated from the shocking post-Shoah realization that replacement-theology had promoted the concrete Christian displacement of Jews. After the Shoah and the Nazis' declared aim to eradicate the Jewish people, the theological idea of one covenant replacing the other was no longer bearable, let alone tolerable; a Christian theology of replacing Israel could no longer be perceived as merely a harmless abstraction. As a theory, supersessionism represented not just displacement but eliminatory thought, the most aggressive and destructive type of thought possible.

Still, causality had not been proved: it would be a Eurocentric (Occidentalist) mistake to conclude that supersessionist thought necessarily promotes genocidal tendencies. Historically this happened in western Europe, but a complex interplay of factors led to the genocide and it remains complicated to assess their individual impacts. Most scholars would agree that "Nazism was not a Christian phenomenon," but at the same time historians and theologians view patterns of anti-

\footnotetext{
${ }^{18}$ Anidjar, 258.
} 
Judaism as clearly promoting antisemitism as well as physical violence against real Jews. ${ }^{19}$

In short, I want to ask: Is supersessionism necessarily, or only potentially genocidal thought? The Christian idea of covenantal supersession has not directly led to genocide wherever it is preached, and is not to be expected to. A more precise formulation would be: the Christian idea of replacing the people Israel does express a notion of displacement that bears the character of eliminatory thought.

In the intra-Christian ecumenical discussion, the critical assessment of supersessionism has led to tensions between so-called "Western" and non-Western theologies. Is post-supersessionism a Western concept referring to a Western problem? This is an important question for a discourse indicting Christianity for either essentially or mistakenly displacing Jews. Both Nirenberg and Anidjar describe the Christian tradition they talk about as "Western." Clearly, the history of Christian anti-Jewish violence is primarily a history of the West. But this historical observation just increases the difficulty of describing the connection between potentially violent thought traditions and actual atrocities. If non-Western Christianity shared the basics of the Christian thought traditions (such as the idea of supersessionism) but produced considerably less violence, we would certainly need more complex models of historical analysis.

Clearly, the most profound change in Christian self-understanding vis-à-vis Judaism in the $20^{\text {th }}$ century is the reversal of the Christian idea that it replaces Israel. The disavowal of another religious community's legitimacy might seem to be rather trivial to address. But the Christian example shows how the correction of such a tradition exposes and unravels a complex entanglement of truth and distortion, difficult to differentiate. Even the academic world often holds the distortions as the more "authentic" version. Christian identity that is not substitutionary seems infeasible. Maybe it is not surprising that even historians often trivialize major Church statements rejecting supersessionism as expressions of a transient, guilt-ridden "political correctness." While this kind of skepticism seems to be in itself ahistorical, it can serve as a helpful reminder that change in Christian self-understanding is anything but simple: when the Church renounces the idea of replacing the people Israel, it affects/touches many other layers and dimensions of Christian core traditions.

Most recently, the fiftieth anniversary of Nostra Aetate inspired scholars to assess the achievements of the Catholic as well as the ecumenical reformulations of Christian theological approaches to Judaism. One way to evaluate that unprecedented renewal is to ask what of its aspects and methods can be useful to inform contemporary Abrahamic relations. ${ }^{20}$ Edward Kessler's Introduction to Jewish-

\footnotetext{
19 "A Jewish Statement on Christians and Christianity," in: Christianity in Jewish Terms, ed. by Tikva Frymer-Kensky, David Novak, Peter Ochs, David Fox Sandmel and Michael A. Signer (Boulder, Colorado: Westview Press, 2000), xix.

${ }^{20}$ I use the term "Abrahamic" to refer to the interrelationships between Judaism, Christianity and Islam, without making any presupposition regarding their degree of closeness. For a most interesting interpretation of the term, see Mark Silk, "The Abrahamic Religions as a Modern Concept," in The
} 
Christian Relations seems almost organically to lead to such a question, as is implied in the title of its final chapter. "The Wider Interfaith Encounter" discusses Islam's joining the long established Jewish-Christian dialogue. ${ }^{21}$ Kessler sees overcoming supersessionism as one of the core achievements of Jewish-Christian dialogue and encourages Muslims to learn from this.

However, before moving to Kessler's conclusion, one needs to ask carefully whether trilateral relations actually face problems similar to those that shaped early Jewish-Christian dialogue. ${ }^{22}$ Tariq Ramadan's most recent account of Abrahamic relations, published in one of the few comprehensive volumes on the topic, the Oxford Handbook of Abrahamic Relations, does not present supersessionism as a trait of Islam and consequently as something in need of overcoming:

From the Islamic perspective it is entirely understandable that the earliestformed monotheistic religion, Judaism, would not acknowledge the two subsequent monotheistic religions (Christianity and Islam) as the truth because the receipt of God's revelations through the three different historical periods is a sequential process. Similarly the final monotheistic religion can acknowledge the previous two monotheistic religions as they are recognized as being early parts in the sequence of God's entire revelation, which becomes complete with Islam, according to Muslims. ${ }^{23}$

As Tariq Ramadan describes it, instead of being based on supersessionist thought, Islam is deeply rooted in an interreligious logic of revelatory succession that holds the previous religion as God-willed:

The teachings of Islam, as the last established monotheistic religion, make clear that the religious traditions that preceded it will continue to exist, and that the original unity of humankind, in its essence, is expressed even in the diversity of religions, civilizations, cultures, languages and nations. Diversity is the will of God, and it is incumbent upon humankind to transform it into a positive factor in its progression towards the good. ${ }^{24}$

Therefore, contra Kessler, the lesson of Christian-Jewish relations cannot simply be extended to include Islam.

Oxford Handbook of the Abrahamic Religions, ed. Adam J. Silverstein and Guy Stroumsa (Oxford: Oxford University Press, 2015), 71-87.

${ }^{21}$ Kessler's Introduction to Jewish-Christian Relations (Cambridge: Cambridge University Press, 2010) is one of the first comprehensive assessments looking both at historical and theological dimensions of Jewish-Christian relations with a contemporary perspective.

${ }^{22}$ This question has been picked up by John Roth and Leonard Grob in their edited collection of articles entitled Encountering the Stranger: A Jewish-Christian-Muslim Trialogue, Jewish-ChristianMuslim Trialogue, (Seattle, WA: University of Washington Press, 2012).

${ }^{23}$ Tariq Ramadan, "Islamic Perspectives," in The Oxford Handbook of the Abrahamic Religions, 597.

${ }^{24}$ Tariq Ramadan, Islam: The Essentials (London: Penguin Random House, 2017), 66. 
Kessler's proposal requires a theory of interreligious delegitimization, an understanding that might be called an "essentialism of successive religions," i.e., the unavoidable devaluation by the younger religion of the previous revelation. What does it mean for such a theory to understand that Islam is not rooted in a logic of supersession as has been frequently presupposed by scholars of Jewish-Christian relations? It means that supersessionism needs to be seen as a specific set of dynamics enacted by Christianity towards Judaism. The non-supersessionist stance of Islam clearly shows that revelatory succession does not inherently require devaluation. This insight, then, supports investigating Christianity's tendency to engage in delegitimization rather than presuming that this supersessionism is a necessary consequence of being a child of an established revelation. This can be pursued in a number of different ways.

\section{Critiquing the Historical Basis for Supersessionism}

Historical perspectives strongly support the theological and moral repudiation of supersessionism. Remarkably, something that proved morally wrong in theology eventually proved wrong in history too. The critique of supersessionism has led, for instance, to a revision of historical research on the beginnings of Christianity and Judaism, a field often described as "Parting of the Ways." It is fascinating to see the manifold entanglements of contemporary identity discourse and academic research in the study of how Judaism and Christianity came into being. Daniel Boyarin's research pointed to a centuries-long entanglement of practices and convictions, especially when looking at individuals who for centuries could still perceive themselves as following Jesus while also observing Judaism. ${ }^{25}$ The current research trend is strongly influenced by Boyarin's work and envisions the emergence of two distinguishable communities as a long and complex process. Research about the emergence of Judaism and Christianity is still blossoming, now often referred to as "The Partings of the Ways or The Ways That Never Parted." ${ }^{\prime 26}$ The academic discussion on the parting of the ways exemplifies the interrelationship between historical research and theological critique. Christianity has never replaced Judaism, either in dogma or in history.

But every re-reading of history bears its own potential for anachronism. The emergence of Judaism and Christianity was probably neither a "good divorce" nor a clear-cut division of properties. This understanding of ongoing entanglement further complicates the map for any reflection on violence in Christian thought. While the previous description of the field, "The Parting of the Ways," implicitly suggests a separation on account of negative interactions, the view la-

\footnotetext{
${ }^{25}$ Daniel Boyarin, Border-Lines: The Partition of Judaeo-Christianity (Philadelphia: University of Pennsylvania Press, 2004).

${ }^{26}$ The Ways That Never Parted. Jews and Christians in Late Antiquity and the Early Middle Ages, ed. Adam H. Becker and Annette Yoshiko Reed (Minneapolis, MN: Fortress Press, 2007). See also James D.G. Dunn, The Partings of the Ways: Between Christianity and Judaism and their Significance for the Character of Christianity (London: SCM Press, 1991).
} 
belled as "The Ways that Never Parted" subtly points to positive interactions and a certain persistent mutuality in communication and influence.

The critical analysis of aggressive patterns in Christian thought itself needs to be refracted through a lens that detects historical conclusions according to results. Historians themselves are not immune to anachronism. David Nirenberg for example, has tried to trace patterns of aggressive Christian anti-Judaism back to the text of the gospels. The synoptic gospels were composed in the last third of the first century, although they include earlier material going back to Jesus' generation. ${ }^{27}$ But according to Boyarin, the Gospels cannot be understood as "Christian" texts; he sees them as Jewish writings. Recently, Boyarin has even stated that not just the main characters, Jesus and the disciples, but also the authors and redactors of the gospel compositions were Jewish. ${ }^{28}$ But even if only the core text were regarded as "Jewish," one could still criticize Nirenberg through Boyarin: How does one describe the essence of Christian aggression towards Jews with New Testament texts that need to be historically described as "Jewish" rather than "Christian" texts? The methodological problem has not been solved yet. In order to trace patterns of Christian violent thought towards others, namely Jews, scholars try to go back to the earliest sources. But it is anachronistic to call these compositions "Christian." A preliminary conclusion might be that interreligious theory needs to be developed in correspondence with the historical research on the multi-layered and dynamic emergence, disentanglement as well as interconnectivity of thought traditions that we later came to call "Christian" and "Jewish."

\section{Supersessionism, Abrogation and Denigration of the Law}

While the critique of supersessionism has found broad support in Western theologies and mainstream churches, versions of implicit delegitimizing are still present in contemporary Christian thought. Neither systematic theologies nor the exegetical disciplines still present the old covenant as superseded or inferior, and Christian textbooks do not explicitly delegitimize Judaism. Nevertheless, devaluation and replacement as thought patterns still prove influential in Christian discourse as soon as theologians talk about Judaism indirectly, or when they assume that what they are saying does not concern Judaism. For example, such thinking comes into play whenever Christian theologians mention "the law"nomos, commandments, legal texts - and especially when they do not translate the term back to "Torah." The critique of abrogating "the law" began well after the critique of supersessionism, but the two inner-Christian self-critical discussions are connected.

Academic Christian discourse challenging traditions about abrogating "the law," appears in the recent research on the Pauline epistles. Contemporary critical Pauline studies began with E.P. Sanders and are today effectively presented by

\footnotetext{
${ }^{27}$ The redaction of the gospel of John is usually dated as of the beginning of the second century.

${ }^{28}$ Daniel Boyarin, The Jewish Gospels: The Story of the Jewish Christ (New York: The New Press, 2012), 22.
} 
John Gager under the label of the "New Perspective." ${ }^{29}$ This revisionist understanding argues that Paul was not simply dissatisfied with a life of Torah and mitzvot and thus turned to Christ. Rather, according to Gager and others, the conventional portrayal of Paul as a convert is an anachronistic reading of the epistles. "New Perspective" exegetes strongly oppose defining Paul as antinomian, which they argue is an anti-Jewish projection. How to describe Paul's approach to the law positively, however, still remains a challenge. Sanders' formulation expresses this search as Paul's search: "He knew that righteousness is only by faith in Christ, but he still tried repeatedly to find a place for the law in God's plan...,"30

Theologically as well as historically oriented scholars have thus successfully critiqued both Christian supersessionism as a broad phenomenon and the specific exegetical theme of abrogating Torah. While its contexts have varied, the critique of supersessionism has become mainstream both in academic, para-academic and religious institutions. This is particularly manifest in New Testament research with the profound change in the hermeneutics applied to the Pauline epistles. Here, the rejection of anti-Jewish readings of Paul's use of nomos by pioneering exegetes in the eighties, has become mainstream in the $21^{\text {st }}$ century.

New Testament studies here have proven to be a fruitful setting for critical interreligious discourse. Historical arguments became especially helpful in revising anachronistic readings of Paul as a convert exchanging an "inferior" Jewish observance for a "superior" Christian belief. Contemporary Christian approaches to law formulated within other theological disciplines, such as homiletics or ethics, typically lack the corrective potential of these kinds of New Testament historical studies that seek to connect "law" to Torah and commandments. Thus today, when "law" is not explicitly identified as connected to Judaism, it is more likely to be depicted as at its end, overcome and spiritually obsolete. ${ }^{31}$

\section{B. Historicized Eschatology}

While the critique of supersessionism has had a substantial and far-reaching impact on several interreligious and historical discourses, only a small circle of Christian scholars have participated in the analysis and remediation of historicized eschatology, the view that we are currently living in a world already reconciled with God. There are many reasons for this discrepancy, but the most obvious is that the notion of supersessionism is fundamentally an interreligious statement while the realm of eschatology belongs at first sight to the inner realm of Christian doctrine. Although several Catholic and Protestant, American and European theologians have convincingly demonstrated that historicized eschatology directly affects non-Christians, it has not been widely recognized as an expression that impacts upon the interreligious realm.

\footnotetext{
${ }^{29}$ John Gager, Reinventing Paul (New York: Oxford University Press, 2002).

${ }^{30}$ E.P. Sanders, Paul, the Law and the Jewish People (Philadelphia: Fortress, 1983), 199.

${ }^{31}$ David S. Cunningham, Christian Ethics: The End of the Law, (New York: Routledge, 2008).
} 
In her path-breaking 1974 book Faith and Fratricide, Rosemary Radford Ruether already precisely diagnosed this problematic aggression as manifest in Christology. She described "realized eschatology" as an inappropriately accelerated spiritual future meaning that the eschatological is too-eagerly presented as history. ${ }^{32}$ In a realized eschatology, the core of the Christ-message, i.e., reconciliation with God and forgiving of sin, has already been completed. Therefore, expectations for God's future activity, such as reconciliation of all and salvation, have been transferred to the past. This has ethical implications.

In Ruether's view, the contrast between the obviously not reconciled present and these expectations tends to lead to aggression toward those who personify the fact that salvation remains unrealized and even remote, i.e., towards Jews and Judaism. In order to limit this potential aggression, christology needs to shift its temporal mode: reconciliation with God and, even more so, any notion of salvation must belong to the distant future. Ruether's diagnosis is shared by a small circle of theologians engaged in a revision of Christian theology vis-a-vis Judaism. It has been outstandingly implemented by Marquardt, who dedicated three volumes of his seven-volume dogmatics to eschatology and thus created a remarkable shift of theological thought from the past to the future. ${ }^{33}$ Still, only a few systematic theologians have applied this concept of a delayed salvation to the structure of their dogmatic concepts, perhaps because aggression in realized eschatology has not been as obvious as in supersessionism. ${ }^{34}$ In contrast, an emphasis on the work of reconciliation yet to be done both with God and among humans does appear in numerous Christian-Jewish dialogue documents. ${ }^{35}$

One of the immediate implications in the interreligious realm of allowing the eschaton back into future is giving up missionary activity towards Jews. The latest official Vatican interpretation of Nostra Aetate explains the theological connection. Salvation is allowed back into God's hands. Thus, Jews are considered "saved" in their immediate relationship with the one God, without conditioning salvation on a "Christ connection.,"36

\footnotetext{
${ }^{32}$ Rosemary Radford Ruether, Faith and Fratricide: The Theological Roots of Anti-Semitism (New York: Seabury Press, 1974), 246. Ruether did not coin the term "realized eschatology." The locus classicus of the concept is C.H. Dodd, The Parables of the Kingdom (London: Nisbet and Co., 1935).

${ }^{33}$ Friedrich-Wilhelm Marquardt, Was dürfen wir hoffen, wenn wir hoffen dürften? Eine Eschatologie, (Gütersloh: Kaiser, Vol I, 1993; Vol II, 1994; Vol III, 1996).

${ }^{34}$ A striking example of a realized eschatology that does not show signs of the aggressive potential described here is Paul Tillich, Systematic Theology, vol. 2, Existence and the Christ (Chicago: University of Chicago Press, 1957).

${ }^{35}$ The joint Jewish-Christian document "A Time for Recommitment: The Twelve Points of Berlin" calls for social justice and peace while combatting antisemitism and racism. The document is available on the website of the International Council of Jews and Christians: http://www.iccj.org/BerlinDoc.3594.0.html.

${ }^{36}$ See "'The Gifts and the Calling of God Are Irrevocable': A Reflection on Theological Questions Pertaining to Catholic-Jewish Relations on the Occasion of the $50^{\text {th }}$ Anniversary of 'Nostra Aetate' (No. 4)," Commission for Religious Relations with the Jews (10 December 2015), http://www.vatican.va/roman curia/pontifical_councils/chrstuni/relations-jewsdocs/rc pc chrstuni doc 20151210 ebraismo-nostra-aetate en.html.
} 
How do a realized eschatology and a lack of interest in ethics correlate? When the substance of reconciliation is believed to be already achieved, there is less need to reflect upon matters and methods of building just relationships between individuals and communities. The Swiss Reformed theologian Dietrich Ritschl is one of the very few systematic theologians deeply involved in dogmatic as well as ethical discourse. He thematized what he calls the "unfulfilled talk of reconciliation" within a Christology striving for interpersonal care and understanding. ${ }^{37}$ According to Ritschl, the explicit acknowledgement that God's reconciliatory work is not complete effectively underlines the value of human reconciling efforts. Along these lines, Christian post-Shoah thought generally postulates a certain delay of Godly reconciliation and makes instead an explicit call for human efforts at reconciliation, such as the pursuit of social justice, peace and the taking of responsibility for the needs of others.

A general re-evaluation of ethics would be a logical consequence of theological attempts to relegate eschatology's last matters to the future. But unlike Levinas and late twentieth-century moral philosophers, ${ }^{38}$ only very few Christian theologians have explicitly called for an "ethical turn." Friedrich-Wilhelm Marquardt is again a prime exemplar of an exception. He has tried to argue for a Christian re-assessment of praxis. His deep appreciation of deeds, works and action is certainly to be understood as part of a radical, specifically Lutheran postShoah self-critique. In a highly unusual, even unique move, Marquardt turned to develop an idea of Christian practice that he called "Evangelical Halakhah."39 The idea is not to re-establish Christianity as a law-based religion, but to regain an understanding of human action as primary expression of the Christian faith. Interestingly, Marquardt develops his idea of gospel-centered "law" within his eschatology, which supports my theory of a correlation between the critique of realized eschatology and a Christian turn to praxis, ethics and law.

A reinforced Christian appreciation for commandments is a common feature of Jewish-Christian dialogue, while rethinking divine judgment within nonfundamentalist Christianity is a rather particular component of post-Shoah thought. The Catholic theologian Gregor Taxacher comes closest to Marquardt's focus on eschatology as the framework for discussing ethics and divine judgment, although he defines his field mainly through the term "apocalypse." $" 40$ The systematic theologian Catherine Keller also frames ethical discourse under this

\footnotetext{
${ }^{37}$ Dietrich Ritschl, The Logic of Theology (Philadelphia: Fortress Press, 1987), 137f.

${ }^{38}$ Cf. Adi Ophir, The Order of Evils: Toward an Ontology of Morals (New York: Zone Books, 2005), 20.

${ }^{39}$ The use of this term has been criticized, as it dismisses the character of Jewish Halakhah as well as Christianity's inner grammar as not being a law-based religion. See, for instance, Barbara U. Meyer, "Welches Gesetz ist heilig, gerecht und gut, und für wen?," in Biblische Radikalitäten. Judentum, Sozialismus und Recht in der Theologie Friedrich-Wilhelm Marquardts, ed. Andreas Pangritz (Würzburg: Ergon, 2010), 129-140.

${ }^{40}$ Gregor Taxacher, Apokalypse ist jetzt. Vom Schweigen der Theologie im Angesicht der Endzeit (Gütersloh: Gütersloher Verlagshaus, 2012).
} 
rubric. $^{41}$ Both theologians aim at reintegrating apocalyptic thinking into nonfundamentalist theology and ethics. As Kathryn Tanner has shown in a comprehensive study, many ethically engaged theologians choose eschatology as their key theological discipline. ${ }^{42}$ Theologians involved in Jewish-Christian study and dialogue are usually critical towards any traditional Christian disregard of law and commandment, which they typically depict as a form of anti-Judaism. But this criticism does not automatically lead to formulations of constructive lawconnected theology, nor to an emphasis on ethics. Thus, Marquardt remains a singularly outstanding voice in responding extensively to Ruether's criticism of the impact of a prematurely realized eschatology and the violence it can cause.

\section{Inclusivism}

The third pattern of violent thought to be discussed here is probably the least agreed upon within the Christian academic community, while finding easy consensus among Jewish scholars examining Christianity. I label this pattern of thought "inclusivism." To include everybody, i.e., in Christian communal language, "to welcome everyone" or "to invite everyone in," is usually not recognized as a form of aggression by Christians. While many Christians recognize missionary thought as connoting aggressive attitudes of superiority and disrespect, many fewer recognize that invitations to unity and expectations of integration can be received as eradicating difference.

The Talmud scholar, Daniel Boyarin, recognizes both sides of this issue. In his book A Radical Jew, he presents Judaism and Christianity as complementary. On the one hand, he admires Christianity's caring about all peoples of the world and criticizes (what he sees as) Jewish indifference toward non-Jews. On the other hand, he notes that "the genius of rabbinic Judaism is its ability to leave other people alone. ${ }^{, 43}$ Boyarin thus sees Christianity's missionary inclination as a direct expression of its caring overmuch about everybody not Christian. Christianity, in his understanding, is inherently missionary. He is not alone in this view: since the Enlightenment, multiple liberal Christian theologies have distanced themselves from missionary practice. In the twentieth century, missionary theory has also come under criticism. Mainstream Churches have officially renounced the practice and, even more relevant for the discussion of inclusivism, criticized proselytizing Jews even at the theoretical level. ${ }^{44}$

\footnotetext{
${ }^{41}$ Catherine Keller, Apocalypse Now and Then: A Feminist Guide to the End of the World (Minneapolis: Augsburg Fortress Publishers, $2^{\text {nd }}$ edition 2004).

${ }^{42}$ Kathryn Tanner, "Eschatology and Ethics," in The Oxford Handbook of Theological Ethics, ed. Gilbert Meilaender and William Werpehowski (Oxford: Oxford University Press 2005), 41-56.

${ }^{43}$ Boyarin, A Radical Jew, $232 \mathrm{ff}$.

${ }^{44}$ See the theological argumentation against missionary approaches towards Jews in the 2015 Vatican's interpretation of Nostra Aetate, \&6: "The Church is therefore obliged to view evangelization to Jews, who believe in the one God, in a different manner from that to people of other religions and world views. In concrete terms this means that the Catholic Church neither conducts nor supports any specific institutional mission work directed towards Jews." Commission for Religious Relations with the Jews, "The Gifts and the Calling of God Are Irrevocable" (Rom 11:29): A Reflection on Theolog-
} 
Boyarin closely connects and even identifies inclusivism with the missionary ideal. His critique of Christianity is built on his reading of Paul, especially the Epistle to the Galatians, and especially on one verse of this early and overly polemical letter. Galatians 3:28 is a remarkable choice as a proof text for Christian inclusivism, in so far as it has been for centuries the favorite verse of egalitarian and liberation movements within Christianity. It reads: "There is neither Jew nor Gentile there is neither slave nor free, neither man nor woman for you are all one in Christ." In Boyarin's understanding, this verse sums up the Christian eradication of all difference. To New Testament scholar Lloyd Gaston the same verse states the equal value of Jewish and Gentile identity and "means that in Christ there is both Jew and Greek, both male and female. Just as women do not need to become men nor men women to attain their full humanity, so Jews do not need to become Gentiles nor do Gentiles need to become Jews." ${ }^{45}$ In his foreword to his book on Paul, Boyarin presents this verse as his personal hermeneutical key to all Pauline epistles (which are rather diverse in style, choice of topics, as well as addressees).

Does the Pauline emphasis on unity over division entail aggression? In Jewish as well as Christian post-Shoah thought, this is often implicitly agreed upon, with the prevailing understanding of otherness being that it necessarily resists this striving for sameness. This kind of thinking is often influenced by Levinas' ethics of responsibility for the otherness of the other. Friedrich-Wilhelm Marquardt has described the Shoah as an attack on the otherness of all others, and in response he calls for the protection and even promotion of otherness. ${ }^{46}$ Early $21^{\text {st }}$ century interreligious thought presents difference as part of the solution, not the problem. Jonathan Sacks' post 9/11 book The Dignity of Difference: How to Avoid the Clash of Civilizations expresses this view in its very title. ${ }^{47}$ Failure to dignify difference is aggressive. Sacks differs from Boyarin in not equating one particular religion with the striving for unity or uniformity, but he shares Boyarin's positive attitude to difference as a key prerequisite of dignity.

Only most recently, the study of difference has developed a more critical side, especially when women philosophers examine the politics of difference and "othering." A very recent example is Rita Dhamoon, who reads the politics of difference solely through the lens of power. ${ }^{48}$ In her view, the notion of "difference" is generally used to serve the normative power constellations rather than to challenge them. Dhamoon's field is not religion but culture and her main object of criticism is multicultural theory. But her approach is important for the contemporary critical interreligious discourse that has developed an overwhelmingly

ical Questions Pertaining to Catholic-Jewish Relations on the Occasion of the $50^{\text {th }}$ Anniversary of "Nostra Aetate," 2015.

${ }^{45}$ Lloyd Gaston, Paul and the Torah (Eugene, OR: Wipf and Stock, 2006), $33 f$.

${ }^{46}$ Marquardt, Eschatology, vol. 1, 184.

${ }^{47}$ Jonathan Sacks, The Dignity of Difference. How to Avoid the Clash of Civilizations (London: Bloomsbury Academic, $2^{\text {nd }}$ edition 2003).

${ }^{48}$ Rita Dhamoon, Identity/Difference Politics: How Difference is Produced and Why it Matters (Vancouver: UBC Press, 2009). 
positive stand on difference. ${ }^{49}$ Considering Dhamoon's prism of power relations helps mitigate the idealizing of difference as an automatically critical principle.

But does this contradict Boyarin's indictment of the Christian overriding of difference as a key form of aggression? Does seeing inclusivism as aggression presuppose a certain idealization of difference and otherness? In that case, Dhamoon's notion of difference and power-relations would be closer to Nirenberg's historiography of "othering." Nirenberg tries to construct a meta-theory that would explain Christian aggression towards Jews and Judaism over the centuries. In his view, the Christian church repeatedly produces the Jews as Other. The theory obviously works for the combination of Christianity and power, but then the question remains as to how much Christian culture and how much power is needed to enact that mechanism of othering. Interestingly, Boyarin's thesis about Christianity posits the opposite. For him, the desire for unity equals an urge for sameness and is not just a source but rather the main source of aggression in Christianity. Nirenberg and Boyarin agree upon violence rooted in Christian attitudes to inclusivity. But while Boyarin identifies the Christian ideal of inclusion as core aggression in itself, Nirenberg sees Christianity as responsible for constructing difference in a process he describes as "othering". According to Boyarin, inclusivism is the root of Christianity's violence, while Nirenberg describes Christianity's aggression as a pattern of repeated exclusion. Both scholars try to formulate an essence of violence in Christianity, with Boyarin presenting the root of aggression as a general attitude going back to Paul and Nirenberg describing Christian aggression as repeated behavior. Neither refer to changes in Christian thought or history.

Historically and textually, Boyarin attributes the Christian eradication of difference to Paul. But, as we have noted, Pauline studies have been revolutionized since his book appeared in 1994. Boyarin's Galatian-based, difference-eradicating Paul is precisely the old Paul of traditional anti-Jewish Protestant exegesis. It is precisely the Paul who was presented as having abolished the law, beginning with circumcision, the physical mark of difference. But "New Perspective" scholars have come to the conclusion that Paul's approach to circumcision is complex and that he holds the Jewish people's specific signs as holy. ${ }^{50}$ In other words, Paul should not be read as erasing difference.

Does this reversal in Pauline exegesis falsify Boyarin's thesis on Christian aggressive inclusivism? It may change our understandings of Paul, but it doesn't change the historical reality of how Christians lived according to the old understandings. Christians have striven for sameness both within Christianity as well as beyond. Both the demands for intra-Christian uniformity and for external missionary activity have been aggressive and violent. Thus, if today's ecumenical ideal of Christian unity still seeks the eradication of difference, it contains within it the potential for violence. It is thus significant that the Catholic church refrains from organized mission towards Jews and that Catholic scholars speak of Jewish

\footnotetext{
${ }^{49} \mathrm{Cf}$. Sacks, The Dignity of Difference.

${ }^{50}$ See Sanders, Paul, the Law and the Jewish People, 143-162.
} 
otherness as holy. ${ }^{51}$ While aggression towards different denominations and religions is a strong historical component of Christianity, the recent regard for otherness is now a historical fact. The new reading of the old Pauline texts undergirds this discourse about an essential matter in Christian hermeneutics of the other. It thus falsifies Boyarin's thesis only when applied to the present.

\section{Abrahamic Implications of the Patterns of Violence}

\section{A. Romans 10:4 and Christian Attitudes to the Law}

Nirenberg's research points to the phenomenon of using the term "Jewish" and "Judaism" as a chiffre for all kinds of negatively presented attitudes. This begins already in New Testament writings with the negative use of the verb "to judaize." As stated above, Nirenberg rightly notes that there is no necessity for the presence of actual Jews in order to enact anti-Semitism (or philosemitism). He thus speaks on occasion of "the imaginary role of Jews," who amply serve a function even in their physical absence. ${ }^{52}$

Examining the role of law in interreligious relations shows that there is no necessity for any word of the word-family Jew/Jewish/Judaism, nor even for the verb "to judaize" in order to evoke and perpetuate anti-Judaism. This is best exemplified by the interpretation history of Romans 10:4, "Christos is the telos of the nomos" often translated as "Christ is the end of the law." In this traditional translation, the sentence expresses supersessionism par excellence, without any mention of Jews or Judaism. But the Greek word telos also means fulfillment, aim, target, or destination. The notion that Paul mostly has Torah in mind when he writes nomos, once a pioneering reading, has become a widespread exegetical insight. ${ }^{53}$ Thus, some exegetes today prefer translations equivalent to "Christ is the aim of Torah. ${ }^{, 54}$ While the English word "end" also holds an echo of telos, the German equivalent "Ende" does not, carrying only a sense of finality.

When it comes to the theological topic of law (nomos), even liberal contemporary Christian theologies still display the logic of replacement, especially within Christology and the idea of Christ as "end of the law." However, today, the Christian logic of abrogating the law has transcended the relationship to Judaism. Within Jewish-Christian relations, supersessionist thought has been corrected and, especially in Catholicism, officially rejected. The Christian reversal of abrogating Torah could itself rely on Pauline theology. But the logic of abrogating and denigrating the law has reached beyond Judaism and thus is even more challeng-

\footnotetext{
${ }^{51}$ Philip Cunningham, "Celebrating Judaism as a 'Sacrament of Every Otherness'," The Theology of Cardinal Walter Kasper: Speaking Truth in Love, ed. Kristen Colberg and Robert Krieg (St. John's MN: Liturgical Press, 2014), 223-240.

${ }^{52}$ Nirenberg, Anti-Judaism, 345 for example. See also, for instance, Paul Lendvai, Antisemitism without Jews: Communist Eastern Europe (Garden City, NY: Doubleday, 1971).

${ }^{53}$ Lloyd Gaston was a pathbreaking scholar in this regard. See his Paul and the Torah (Vancouver, BC: University of British Columbia Press, 1987), which summarizes earlier research.

${ }^{54}$ Ekkehard W. Stegemann, Paulus und die Welt. Aufsätze, ed. Christina Tuor and Peter Wick (Zürich: Theologischer Verlag Zürich, 2005), 56.
} 
ing to reverse. Theological delegitimizing of religious law also affects thinking about Islam. With regard to Judaism, mainstream Christianity underwent a process of self-criticism that was strongly supported by new exegetical insights, especially the "New Perspective" in Pauline scholarship. Christian hostility toward Islamic laws has no such immediate corrective. It remains to be seen whether an Abrahamic version of the discourse on displacement thought can facilitate more complex readings of the dynamics between Christian thought traditions, delegitimization and the denigration of law.

\section{B. Translating the Abrogation of the Law into Secular Antinomian Thought}

All three Christian patterns of potential violence, supersessionism, realized eschatology and inclusivism translate into secular language. Disconnected from their original religious contexts, their violent implications appear even more blatantly. Again, causality of necessity is impossible to prove since not all Christian contexts that hosted versions of these three aggressive impulses put aggression into action. Likewise, physical violence cannot be indisputably predicted as a direct result of these thought patterns, including their secularized versions.

Supersessionism, the notion that one religious community supersedes and replaces another, bears the character of eliminatory thinking. In his moral philosophy The Order of Evils, Adi Ophir states that labeling a certain group as superfluous often precedes the application of genocidal rhetoric. ${ }^{55}$ This would be a direct secular translation of the idea of supersessionism: Since Christianity has superseded Judaism, the Jewish People has become obsolete. The specific interreligious dynamics expressed in Christian supersessionism find a counterpart in the Western genocide of Jews. For this reason, Christian post-Shoah thought is necessarily decisively post-supersessionist. Contemporary Christian theology is unlikely to maintain today the claim that Judaism as such is obsolete or that the Torah is "superfluous." But the notion that the law is not constitutive for salvation does still represent mainstream Christian thought. The Lutheran emphasis on grace and faith declares the law as secondary, a theological hierarchy with ample implications. ${ }^{56}$ Hence despite the remarkable achievements of post-Shoah reform, the potential for violence still remains embedded in this Christian concept and its implications.

The concept of realized eschatology directly connects to divestment from ethics. When the world is assumed to be already fundamentally redeemed, ethics, the reflection on deeds and good works themselves receive secondary importance. Obviously, this is contrary to post-Shoah thought; that typically starts from the awareness of destruction and the recognition of the urgent need for repair. ${ }^{57}$

\footnotetext{
${ }^{55} \mathrm{Cf}$. Ophir, The Order of Evils, $510 \mathrm{ff}$.

${ }^{56}$ The critique of concepts of "law" in Protestant theology is a recurring theme of Marquardt's dogmatics throughout, see especially Friedrich-Wilhelm Marquardt, Eschatologie I, 241ff.

${ }^{57}$ Cf. Emil Fackenheim, To Mend the World: Foundations of Post-Holocaust Thought (New York: Schocken, 1982).
} 
Moreover, realized eschatology also clearly reduces the significance of law. When the main part of salvation - whether framed in language of enabling justification, as a constitutive act of grace or as the principal triumph over sin-is claimed to have already occurred, anything that advances reconciliation, peace, or justice will be implicitly deemed secondary or redundant. Law, in such a worldview, is not regarded as an expression of human efforts to implement and enhance justice but is reduced to a more regulative function.

Our third category, inclusivism, is complex and cannot simply be equated with disrespect for difference. Whether in the interreligious world or in contexts of cultural integration, efforts to unify are not necessarily more or less belligerent than acts of exclusion. The personal experiences of the relevant scholars seem to have shaped their understandings. While Boyarin, reflecting Jewish experience, holds up particularity and difference almost as an ultimate value, Rita Dhamoon depicts the language of difference as a primary means used by the powerful to maintain unequal relations. Thus, in the secular realm as in the world of religion, inclusion versus exclusion needs to be evaluated within their contexts. Both can be perceived as aggression and need to be judged according to the more vulnerable of the respective groups involved.

Islam is clearly affected by all three patterns we have examined, including both their religious and secular dimensions. Supersessionism, originally the particular dynamic between Judaism and Christianity, is perpetuated through the notion of the superiority of grace over law. Realized eschatology, with its disinterest in ethics and disregard for mending a world believed to be already repaired, supports the respective status quo and trivializes human efforts for global justice. And finally, inclusivism cannot allow for Muslim difference in Western society.

Three structures of violence in Christian thought have been analyzed here, three that have thus far received very different degrees of attention in critiques of Christianity and theories of Christian-Jewish relations. While supersessionism in general has been acknowledged as a destructive Christian attitude towards Judaism and has already been broadly repudiated, substructures of supersessionism, such as the idea of an abrogation or denigration of the law, still impact interreligious as well as intercultural relations. Similarly, the exegetically refuted idea of a devaluation of the Torah has not yet been followed by a Christian appreciation for religious law in general or Muslim legal thought traditions in particular.

The more subtle pattern of realized eschatology has been recognized as violent only by a small circle of theologians. This understanding that salvation has basically been completed leads to a disregard for ethics and reflection on good works. My analysis here shows an interesting convergence of a sub-form of supersessionism, the abrogation of the law, and realized eschatology, as both patterns exhibit disdain for ethical and legal discourse. Finally, inclusivism, with its striving for unity, constitutes the most contested structure of Christian aggression. But even if Boyarin's essentializing Christianity as not allowing for difference remains unconvincing, the discussion of the potential aggressive implications of inclusivism contributes to a necessary reflection on Christianity's violent past. In order to prevent or reduce violence in the future of interreligious 
relations, the discourse about various and combined patterns of aggression is helpful, while the equation of Christianity with violence lacks historical differentiation as well as critical precision much needed for the implementation of change. 